\title{
Oğuzlar 77 Ceviz Üretici Sorunlarının İncelenmesi (Çorum İli Oğuzlar İlçe Örneği)
}

\author{
Rüveyda Yüzbaşığlu* iD \\ *Gaziosmanpaşa Üniversitesi, Ziraat Fakültesi, Tarım Ekonomisi Bölümü, Tokat.
} Sorumlu yazar: ruveyda.kiziloglu@gop.edu.tr

Geliş Tarihi: 25.06.2021

Kabul Tarihi: 18.11.2021

\section{$\ddot{O} z$}

Oğuzlar 77 cevizi üreticilerinin yetiştiricilik ve pazarlama sorunları bu araştırmada incelenmek istenmiştir. Bu amaç doğrultusunda 100 ceviz üreticisi ile görüşülmüştür. Üreticilerin ortalama yaşının 58,10 ve \%64,00'nün ilkokul mezunu olduğu görülmüştür. Üreticilerin 18,28 yıllık ceviz yetiştiriciliği deneyimi olduğu belirlenmiştir. Üreticilerin yetiştirdikleri ürünlerin \%96.00'sı tescilli Oğuzlar 77 ürünü olduğu belirlenmiştir. Üreticilerin \%76,00'sı sadece ceviz yetiştiriciliğinden gelir elde etmektedir. Ortalama üretim alanı 10.47 da ve ağaç başına ortalama verim 15,07 kg cevizdir. Üreticilerin \%79,00'u yetiştiricilik problemi yaşamaktadır. Yetiştiricilikteki en büyük problem ise doğal ve iklimsel afetlerdir. Yetiştiricilerin yetiştiricilik problemi değerlendirmelerini işletmecinin yaşı, yetiştiricilik tecrübesi ve ceviz ekim alanı istatistiki olarak etkilediği logit analizi sonucu söylenebilir. Üretilen cevizlerin \%82,00’si toptan olarak tüccarlara pazarlanmaktadır. Üreticilerin \%97,00'sinin pazarlama sorunu yaşamadığı belirlenmiştir. İklim değişikliği gibi doğal afetlerden etkilenen yetiştiricilere sigorta yaptırması ve sigortalatma hakkında eğitim verilmesi önerilebilir. Aile işletmesi olan üreticilerin kadın girişimciliğine yönelik eğitim verilebilir. Cevizin değerlendirilmesi için cevizi sadece ham ürün değil katma değer katacak ceviz reçeli, köme/cevizli sucuk gibi ürünlere dönüştürülerek de kadın işletmeleri kurulması önerilebilir.

Anahtar Kelimeler: Ceviz, İklim Değişikliği, Problem, Üretim

\section{Analysis of Oğuzlar 77 Walnut Producer Problems (Çorum Province, Oğuzlar District Case)}

\section{Abstract}

The cultivation and marketing problems of Oğuzlar 77 walnut producers were investigated in this study. For this purpose, 100 walnut producers were interviewed. It was seen that the average age of the producers was 58,10 and $64,00 \%$ were primary school graduates. It has been determined that the producers have 18,28 years of walnut cultivation experience. It has been determined that $96,00 \%$ of the products grown by the producers are registered Oguz 77 products. 76,00\% of the producers earn income only from walnut cultivation. The average production area is $10,47 \mathrm{da}$ and the average yield per tree is $15,07 \mathrm{~kg}$ of walnuts. $79,00 \%$ of producers have aquaculture problems. The biggest problem in aquaculture is natural and climatic disasters. It can be said as a result of the logit analysis that the age of the operator, the farming experience and the walnut cultivation area affect the farmer's aquaculture problem evaluations statistically. $82,00 \%$ of the walnuts produced are marketed to traders' wholesale. It was determined that $97,00 \%$ of the producers did not experience any marketing problems. It can be suggested that breeders affected by natural disasters such as climate change take out insurance and provide training on insurance. Training for women entrepreneurship can be given to family-run producers. For the evaluation of walnuts, it can be suggested to establish women's businesses by transforming walnuts into products such as walnut jam, kome/walnut sausage that will add value, not just raw products.

Keywords: Walnut, Climate Change, Problem, Production

\section{Giriş}

Cevizin (Juglans regia L.) gen merkezi İran'ın Hazar Denizi kuzey enlemdeki Ghilan Bölgesidir. Bununla birlikte ceviz yetiştiriciliği, Uzakdoğu'dan başlayarak Türkiye ve Avrupa üzerinden Amerika'ya kadar uzanan çok geniş bir bölgede yapılmaktadır (Bayazit ve ark., 2016).

Ceviz hayvansal protein kaynağı yerine geçebilen ve yüksek oranda doymamış yağ asit içerikleri ile değerli bir besin kaynağı olup, kolesterol içermez. Thiamin, vitamin B6, folacin içeren 
birçok vitamin ile demir, çinko, bakır, magnezyum, fosfor ve potasyum açısından oldukça zengindir (Yiğit ve ark., 2005).

FAO 2019 verilerine göre dünya ceviz ekim alanının toplamı 1305 bin hektardır. Dünya ekim alanının \%48,36'sına Çin (631330 ha) sahip oarak birinci sırada yer alırken, \%11,32'sine ABD (147710 ha) sahip olarak ikinci sırada ve \%9,54'üne Türkiye (124553 ha) sahip olarak üçüncü sırada yer almaktadir (FAO, 2021).

FAO 2019 verilerine göre dünyada 51 ülkede toplamda 4,498.442 ton üretim yapılmaktadır. Dünya üretiminin $\% 56,05$ 'ini Çin yaparken, \%5,00'lik kısmını Türkiye üretmektedir. Yani Türkiye 225,000 ton ceviz üretimi ile dünya siralamasında 4. siradadır (FAO, 2021).

Ceviz ekim alanı ve üretim miktarı olarak incelendiğinde Türkiye'nin dünya sıralamasında önemli bir yere sahip olduğu söylenebilir. Ancak verim açısından incelendiğinde dünya ceviz veriminin ortalama $3.446 \mathrm{~kg} / \mathrm{da}$ olduğu Türkiye ortalama veriminin ise $1.807 \mathrm{~kg} / \mathrm{da}$ olduğu görülmektedir (FAO, 2021). Türkiye, coğrafi konumu bakımında Avrupa ve Asya arasında köprü olarak görülürse; $A B$ ceviz verimi ortalama $24.786 \mathrm{hg} / \mathrm{ha}$ ve Asya kıtasının ortalaması ise $3.849 \mathrm{~kg} / \mathrm{da}$ olarak göz önüne alındığında bulunduğu bölgenin konumuna göre verimin altında kalmaktadır. Yani üretim ve ekim alanında zengin olan Türkiye'de verimde azalma olduğu söylenebilir. Bunun sebepleri olarak yetiştiricilikteki problemler görülebilir.

TÜİK 2019 verilerine göre Türkiye'de 79 ilde ceviz üretimi gerçekleşmektedir. Dünyadaki ceviz üretiminin \%5,19'u Türkiye üretmektedir ve Türkiye'de en fazla üretimin yapıldığı il Hakkari (11.682 ton) ilidir. Araştırma kapsamı olan Çorum ili ise 8.581 ton ceviz üretimi ile Türkiye ceviz üretiminin \%3,81'ini oluşturmakta ve 6. sırada yerini almaktadır. Çorum ilinde 3.120 ton ile en fazla üretim yapan ilçe Oğuzlar ilçesidir (TÜíK, 2020). Çorum ilinde üretilen cevizin \%36,36'sını kapsayan Oğuzlar ilçesinin cevizi ayrıca 2010 Yılında Oğuzlar 77 adı altında tescillenmiştir. Günlük ve sofralık tüketime çok uygun olması sebebiyle tercih edilen bir çeşittir (Anonim, 2021). İlçenin geçim kaynağı ceviz üretimiyle karşılanmaktadır. Oğuzlar 77 cevizi üreticilerinin yetiştiricilik ve pazarlama sorunları bu araştırmada incelenmek istenmiştir.

Literatür incelendiğinde ceviz yetiştiriciliği üzerine çeşitli çalışmaların olduğu görülmüştür. Örneğin Almeida (2020) Portekiz'de ceviz üretimi ve pazarlamasını yıllara göre değerlendirmesini incelemiştir. Güvenç ve Kazankaya (2019) Türkiye'nin ceviz üretimi, dış ticareti ve rekabet gücünü incelemişlerdir. Ketenci ve Bayramoğlu (2018) Türkiye'nin ceviz üretiminde rekabet gücünü incelemişlerdir. Ünver ve Sakar (2011) Türkiye'de ceviz yetiştiriciliğinin genel durumunu incelemişlerdir. Yani ceviz üretiminin genel olarak üretim boyutunda yıllar itibariyle çalışmalar mevcut iken işletme boyutunda da çalışmalar mevcuttur. Khanali ve ark. (2021) İran'da ceviz üretiminde girdi-çıktı ilişkisini incelemişlerdir. Ceviz yetiştiricilerinin ekonomik yapısını inceleyen çalışmalara literatürde rastlamak mümkündür (Bostan, 2012; Ketenci ve Bayramoğlu, 2020). Türkiye'nin farklı illerinde ceviz yetiştiricilerinin sosyo-ekonomik yapılarını inceleyen araştırmalar da mevcuttur (Çiftçi ve Gökçe, 2006; Pezikoğlu ve ark., 2012; Yıldız ve Çolak, 2018). Patentli ürün olan oğuzlar 77 cevizinin yetiştiricilik sorunları ve yetiştiricilik sorunlarını etkileyen faktörler bu araştırma ile incelenmek istenmiştir. Literatürde bu amaçlı bir araştırmanın olmaması ayrıca yörede mevcut yapıyı ortaya koyacak çalışmaya rastlanılmaması araştırmanın önemini artırmakta ve bölgedeki yetiştiricilerin sorunlarına 1 şı tutmaktadır.

\section{Materyal ve Metot}

\section{Materyal}

Araştırmanın ana materyalini Çorum İli Oğuzlar ilçesinde 2019 Kasım-Aralık aylarında Ceviz yetiştiren çiftçilerle uygulanan anket sonuçları oluşturmaktadır. Araştırmanın ikincil materyali ise, bu konuda yapılmış çalışmalar (tez, inceleme, derleme vb.) ve konuyla ilgili raporlardır.

\section{Verilerin toplanması aşamasında izlenen yöntem}

Oğuzlar Tarım ve Orman İlçe Müdürlüğü kayıtları incelendiğinde 6 köy ve 7 merkez mahallede ceviz yetiştirildiği yapıldığı, toplamda kayıtlı 716 çiftçi bulunduğu ve bu çiftçilerin \%57'si olan 413 çiftçinin Asarçayı, Birtatlı, Çarşı, Çeşme, Gölbaşı, Karadonlu, Kızılcapelit Mahalleleri olmak üzere 7 Merkez Mahallede toplandığı belirlenmiştir. Bu 7 Merkez Mahalle çiftçisi örnekleme için 
gayeli olarak seçilmiştir. Seçilen bu Mahallelerdeki toplam üretici sayısı 413 kişi olup, üretici sayısının \%25'i ile (100) anket çalışması yapılmıştır.

\section{Verilerin analizi aşamasında izlenen yöntem}

Araştırmada ceviz yetiştiricilerinin yetiştiricilik problemi yaşamasını etkileyen faktörleri binary logit analizi ile belirlenmiştir. Logit modelinde bağımlı değişken kukla ve tahmin edilen olasılık değerleri 0 ile 1 arasında değişmektedir.

Lojistik fonksiyon (LOGIT) genel fonksiyonel formülü (Gujarati, 2001);

$$
F_{i}\left(\beta X_{i}\right)=\frac{\exp \left(\beta X_{i}+\varepsilon_{i}\right)}{1+\exp \left(\beta X_{i}+\varepsilon_{i}\right)}
$$

$\mathrm{F}\left(\beta \mathrm{X}_{\mathrm{i}}\right)=$ İndex fonksiyonunu (I nci ceviz yetiştiricileri için gözlenen yetiştiricilik problemi yaşama durumu, problem yaşamayanlar $i$ çin $\mathrm{j}=0$; problem yaşayanlar için $\mathrm{j}=1$ )

$\beta=$ Açıklayıcı değiş̧kenlerin katsayı vektörünü

$\mathrm{X}_{\mathrm{i}}=$ Ceviz yetiştiricilerin karakterlerini temsil eden açıklayıcı değişkenleri

$\varepsilon_{\mathrm{i}}=$ Hata terimini göstermektedir.

Lojistik katsayılarını anlamak için, bir olayı olasılık oranı bakımından düşünmek gerekir (Akgül ve Çevik, 2005). Olasılık oranının doğal logaritması alınarak elde edilen lojistik regresyon modelinin parametrelerini tahmin ederken en yüksek olabilirlik (maximum likelihood) yöntemi yaygın olarak kullanılır (Berenson ve Levine, 1996).

Lojistik modelde yer alan bazı değişkenler, kategoriler arası farklılıkları olasılık oranları olarak elde edilebilmek üzere kategorik değişkene çevrilmiştir. Yorumlamada kolaylık sağlaması açısından bağımsız değişkenlerin bazıları kukla değiş̧ken olarak modele alınmıştır. Modele açıklayıcı değişken olarak; yetiştiricilerin yaşı (sürekli değişken), eğitim durumu (okur yazar ise 0, ilkokul mezunu ise 1 ve ortaokul ve üstü ise 2 olarak kodlanmıştır), ceviz yetiştiriciliği tecrübesi (10 yıl ve altı ise 0,10 yıl üstü ise 1 olarak kodlanmıştır), ceviz yetiştiriciliği yanı sıra başka işle uğraşma durumu (sadece ceviz yetiştiriciliği yapıyorsa 1, yapmıyor ise 0 olarak kodlanmıştır), ceviz yetiştirme alanı (dekar, sürekli değişken), üreticilerin ceviz yetiştiriciliğinde tarımsal destek alma durumu (destek aldı ise 1, almadı ise 0 olarak kodlanmıştır), ağaç başına ceviz verimi (kg/ağaç, sürekli değişken) ve cevizlerin tescil durumu (tescilli ise 1 , tescilli değil ise 0 olarak kodlanmıştır). Çizelge 1 'de modeldeki bağımlı ve bağımsız değişkenlerin kodları, açıklamaları ve bazı istatistiki özellikleri verilmiştir.

Çizelge 1. Binary logit modelinde kullanılan değişkenlerin tanımlayıcı istatistikleri

\begin{tabular}{|c|c|c|c|c|c|}
\hline Kodu & Değişken & Ortalama & $\begin{array}{l}\text { Standart } \\
\text { Sapma }\end{array}$ & Minimum & Maximum \\
\hline & Ceviz yetiştiriciliğinde problem & & & & \\
\hline $\begin{array}{l}\text { Bagimlı } \\
\text { Değişken } \\
\text { (Y) }\end{array}$ & $\begin{array}{l}\text { yaşıyorsa: } 1 \\
\text { Ceviz yetiştiriciliğinde problem } \\
\text { yașımıorsa:0 }\end{array}$ & 0.790 & 0.409 & 0.0 & 1.0 \\
\hline YAS & $\begin{array}{l}\text { Yetiştiricinin yaş1: } \\
\text { (Sürekli değişken) } \\
\text { Yetiştiricinin eğitim durumu: }\end{array}$ & 58.100 & 10.382 & 26.0 & 80.0 \\
\hline ED & $\begin{array}{l}\text { Okur yazar: } 0 \text {, } \\
\text { İlkokul mezunu: } 1 \\
\text { Ortaokul ve üstü: } 2\end{array}$ & 1.160 & 0.581 & 0.0 & 2.0 \\
\hline TECRUBE & $\begin{array}{l}\text { Ceviz yetisstirme tecrübesi: } \\
10 \text { y1l ve altı: } 0,10 \text { yıl üstü: } 1\end{array}$ & 0.770 & 0.423 & 0.0 & 1.0 \\
\hline UZMANLAS & $\begin{array}{l}\text { Ceviz yetiştiriciliği yanı sıra başka işle } \\
\text { uğraşma durumu: sadece ceviz } \\
\text { yetiştiriciliği yapıyorsa: } 1 \text {, yapmıyorsa: } 0\end{array}$ & 0.240 & 0.429 & 0.0 & 1.0 \\
\hline ALAN & $\begin{array}{l}\text { Ceviz yetiştirme alanı: } \\
\text { (dekar, sürekli değişken) }\end{array}$ & 10.470 & 16.370 & 1.0 & 120.0 \\
\hline DESTEK & $\begin{array}{l}\text { Üreticilerin ceviz yetiştiriciliğinde } \\
\text { tarımsal destek alma durumu: } \\
\text { Destek alan: } 1 \text {, almayan: } 0\end{array}$ & 0.160 & 0.368 & 0.0 & 1.0 \\
\hline VERIM & $\begin{array}{l}\text { Ağaç başına ceviz verimi: ( } \mathrm{kg} / \text { ağaç, } \\
\text { sürekli değişken) }\end{array}$ & 15.07000 & 15.258 & 1.0 & 150.0 \\
\hline TESCİL & $\begin{array}{l}\text { Cevizlerin tescil durumu: } \\
\text { Tescilli: } 1 \text {, tescilli değil: } 0\end{array}$ & 0.960 & 0.197 & 0.0 & 1.0 \\
\hline
\end{tabular}




\section{Bulguları ve Tartışma}

Yetiştiricilikte ürün verimi, pazarlanması gibi üretim faktörleri mevcut durumu ortaya koymakta önemlidir. Sadece ürün üretmek değil yetiştiricinin sosyo-ekonomik yapısının yetiştiricilikte önemli bir yeri vardır. Yetiştiricinin tecrübesi, yaşı, bilgi, tutumu gibi faktörler ürün yetiştirmekte önemli bir yeri olduğu için yetiştiricinin bazı özellikleri Çizelge 2'de verilmiştir.

Yetiştiricinin ortalama yaşının 58,10 ve \%64,00'ünün ilkokul mezunu olduğu Çizelge 2'den gözlenmiştir. Bostan (2012) Bitlis ilinde yaptığı araştırmasında ceviz yetiştiricilerinin ortalama yaşını 49,12 y1l olarak bulmuştur. Çiftçi ve Gökçe (2006) İzmir ve Manisa ilerindeki ceviz yetiştiricilerin ortalama yaşlarının 51,30 yıl ve eğitim süresini 5,37 yıl olarak bulmuşlardır. Pezikoğlu ve ark. (2012) ceviz yetiştiricilerin ortalama yaşının 55 yıl ve eğitim sürelerinin ortalama 6 yıl olarak belirlemişlerdir. Kızılaslan ve Erdemir (2017) kaman ceviz yetiştiricilerinin \%46,79'unun ilkokul mezunu olduğunu tespit etmişlerdir. Türkiye'nin farklı bölgelerinde ve farklı zamanlarda yapılan araştırmaları ile araştırma sonuçları örtüşüp ceviz yetiştiricilerinin aktif çalışabilir yaş aralığında ve çoğunluğunun ilkokul seviyesinde eğitim aldığı anlaşılmaktadır.

Üreticilerin 18,28 y1llık ceviz yetiştiriciliği deneyimi söz konusudur. Yetiştirilen cevizlerin \%96,00'sı tescilli üründür. Pezikoğlu ve ark. (2012) yaptıkları araştırmalarında ceviz yetiştiricilerinin 18 yıllık ceviz yetiştiriciliği deneyimi olduğunu belirlemişlerdir. Üreticilerin \%76,00's1 sadece ceviz yetiştiriciliğinden gelir elde etmektedir. Türkiye'de genelde tarım sektöründe risk ve belirsizlikten dolayı ihtisaslaşma yerine birkaç faaliyet alanndan gelir elde etmeye çalışılır. Balıkesir, Çorum, Denizli, Edirne ve Kahramanmaraş illerini kapsayan bir araştırmada ceviz yetiştiricilerinin \%62,4'ünün tarım dışı geliri olduğuna rastlanılmıştır (Pezikoğlu ve ark., 2012). Ama Oğuzlar ilçesindeki ceviz yetiştiricilerinin gelirinin büyük bir kısmını ceviz yetiştiriciliğinden sağladığı yani ihtisaslaşmanın kısmen olduğu söylenebilir. Üreticilerin \%22,00'si ceviz yetiştiriciliği ile ilgili kooperatife ortaktır ve \%16'sı yetiştiricilik desteği almaktadır. Kızılaslan ve Erdemir (2017) kaman ceviz yetiştiricilerinin \%58,7'sinin bilgi almadığını belirlemişlerdir. Yani yetiştiricilerin kendi bilgi ya da atadan görme bilgi ile yetiştiricilik yaptığı bu araştırmalar sonucu söylenebilir.

Çizelge 2. Yetiştiricilerin sosyo-demografik yapısı

\begin{tabular}{|c|c|c|c|c|}
\hline \multicolumn{2}{|l|}{ Gruplar ve Açıklaması } & Frekans & $\%$ & Ortalama \\
\hline \multicolumn{2}{|l|}{ Yaş } & & & 58.10 \\
\hline \multicolumn{2}{|l|}{ Ceviz yetiştiriciliği deneyimi } & & & 18.28 \\
\hline \multicolumn{2}{|c|}{ Ceviz yetiştiriciliği ile ilgili eğitim alma durumu } & 9 & 9.00 & \\
\hline \multirow{2}{*}{$\begin{array}{l}\text { Ceviz yetiştiriciliği yanı sıra } \\
\text { gelir getirici bir işle uğraşma } \\
\text { durumu }\end{array}$} & Sadece ceviz yetiştiriciliği yapan & 76 & 76.00 & \\
\hline & Başka işle uğraşma durumu & 24 & 24.00 & \\
\hline \multicolumn{2}{|c|}{ Ceviz yetiştiriciliği ile ilgili bir kooperatife üye olma durumu } & 22 & 22.00 & \\
\hline \multirow{8}{*}{ Eğitim Durumu } & Okur yazar değil & 2 & 2.00 & \\
\hline & $\begin{array}{l}\text { Okur yazar ancak herhangi bir okul } \\
\text { mezunu değil }\end{array}$ & 8 & 8.00 & \\
\hline & İlkokul & 64 & 64.00 & \\
\hline & Ortaokul & 19 & 19.00 & \\
\hline & Lise & 6 & 6.00 & \\
\hline & Ön lisans & - & - & \\
\hline & Lisans & 1 & 1.00 & \\
\hline & Yüksek lisans & - & - & \\
\hline \multicolumn{3}{|l|}{ Hanedeki birey sayısı } & & 3.83 \\
\hline
\end{tabular}

Üreticilerin yetiştirilen ceviz alanı, ceviz ağaç varlığı, ağaç başına ceviz verimi gibi bilgiler Çizelge 3'de incelenmiştir. Üreticiler ortalama 10,47 da alanda üretim yapmakta, işletme başına ortalama 123,2 ceviz ağacı düşmekte ve ağaç başına ortalama $15,07 \mathrm{~kg}$ ceviz elde edilmektir. Benzer sonuçlara literatürde rastlamak mümkündür. Çiftçi ve Gökçe (2006) yetiştiricilerin ortalama 5,83 da ceviz alanının olduğu, 45,25 ağaç cevizi olduğu ve ağaç başına ceviz verimini 10,16 kg olarak belirlemişlerdir. Boston (2012) Bitlis ilinde yaptığ 1 araştırmasında yetiştiricilerin 6,45 dekar alan ceviz bahçesinin olduğu ve $149,32 \mathrm{~kg} / \mathrm{da}$ verim aldığını belirlemişlerdir. Pezikoğlu ve ark. (2012) yetiştiricilerin 27 da ceviz arazisinin olduğunu ve 280 adet ceviz ağacına sahip olduklarını bulmuşlardır. 
Ailenin ceviz üretiminde ortalama 2 bireyi çalıştığı belirlenmiştir. Ortalama kabuklu ceviz satış fiyatı 37,50 TL'dir. Literatürde ceviz yetiştiricilerinin cevizlerinin kabuklu olarak daha çok pazarladıkları sonucuna rastlamak mümkündür. Yıldız ve Çolak (2018) Uşak ilindeki ceviz yetiştiricileri cevizlerinin \%65'ini kuru kabuklu pazarladıklarını belirtmişlerdir. Pezikoğlu ve ark. (2012) araştırmalarında yetiştiricilerin cevizlerinin \%57'sini kuru kabuklu satışta bulunduğunu tespit etmişlerdir.

Çizelge 3. Yetiştiricilerin ceviz varlığı

\begin{tabular}{lr}
\hline Varlıklar & Ortalama \\
\hline Ceviz ekim alanı (da) & 10.47 \\
Ortalama yetiştirici başına ceviz ağacı (adet) & 123.2 \\
Ortama ağaç başına ceviz verimi (kg) & 15.07 \\
Ailenin ceviz üretiminde çalışan birey sayısı (kişi) & 2.3 \\
Kabuklu kg satış fiyatı & 37.50 \\
\hline
\end{tabular}

Üreticilerin \%51.00'i ceviz üretiminde teknolojik ekipman kullandığı Çizelge 4'ten anlaşılmaktadır. Üreticilerin \%84.00'ü ceviz yetiştiriciliğinde hiçbir destekten yararlanmadıklarını belirtmişlerdir. Ancak Çiftçi Kayıt Sistemine kayıtlı olan 413 üretici, alan bazlı destek olan Mazot Gübre Desteğinden faydalanmakta olup, üreticilerin bu soruya verdikleri olumsuz cevap bahçe tesisi ve diğer desteklerden faydalanamadıkları şeklinde yorumlanabilir.

Çizelge 4. Üreticilerin ekipman, destek kullanımı

\begin{tabular}{|c|c|c|c|}
\hline Açıklama & & Frekans & $\%$ \\
\hline $\begin{array}{llll}\text { Ceviz } & \text { Üretiminde } & \text { Teknolojik } & \text { Ekipmanlar }\end{array}$ & Kullanan & 51 & 51.00 \\
\hline Kullanma Durumu & Kullanmayan & 49 & 49.00 \\
\hline Üreticilerin Ceviz Yetiştiriciliğinde Destek Alma & Destek alan & 16 & 16.00 \\
\hline Durumu & Destek almayan & 84 & 84.00 \\
\hline
\end{tabular}

Oğuzlar İlçesinde üreticilerin \%96,00'sı tescilli çeşit olan Oğuzlar 77 cevizi ile üretim yapmaktadır. Çizelge 5'te üreticilerin çoğunluğu tescilli çeşitle üretim yaptığını belirtmiş olmakla birlikte \%93,00'lük üretici grubu tescilin ürüne değer kattı̆̆ını düşünmektedir. Tescilli olan kaman cevizi üzerine yapılan araştırma da yetiştiricilerin \%79,8'inin yerli ceviz yetiştirmeyi tercih ettiği sonucu bulunmuştur (Kızılaslan ve Erdemir, 2017).

Çizelge 5. Yetiştirilen ceviz türünün tescil durumu ve kattığı değer durumu

\begin{tabular}{llll}
\hline Açıklama & & Frekans & $\%$ \\
\hline \multirow{2}{*}{ Yetiştirilen ceviz türünün tescil durumu } & Tescilli olan & 96 & 96.00 \\
\multirow{2}{*}{ Tescilin ürüne değer katma durumu } & Tescilli olmayan & 4 & 4.00 \\
& Evet & 93 & 93.00 \\
\hline
\end{tabular}

Çizelge 6'da üreticilerin çoğunluğu $(\% 97,00)$ pazarlama problemi yaşamadığını belirtmiş ve üreticilerin cevizin pazarlama yolları incelendiğinde, çoğunluğunun toptan tüccarlara sattığ1 görülmektedir. Benzer sonuçlara literatürde rastlamak mümkündür. Çiftçi ve Gökçe (2006) İzmir ve Manisa ilindeki ceviz yetiştiricilerinin \%86,67'nin pazarlama sorunu olmadığını ve ürünün \%45,70'ini tüccara sattığını belirtmişlerdir. Pezikoğlu ve ark. (2012) 5 ili (Balıkesir, Çorum, Denizli, Edirne, Kahramanmaraş) kapsayan araştırmalarında yetiştiricilerin \%18,3'ünün pazarlama sorunu yaşadığını ve ürünün \%50,8'ini tüccara toptan pazarladığını bulmuşlardır. Kızılaslan ve Erdemir (2017) araştırmalarında yetiştiricilerin cevizlerinin \%70,8'ini tüccara pazarladıklarını göstermişlerdir. Benzer sonuçlar olduğu gibi farklı sonuçlara da rastlamak mümkündür. Bostan (2012) Bitlis ilinde yaptığı araştırmasında ceviz yetiştiricilerinin \%31,25'inin pazarlama sorunu olmadığını yani büyük bir kısmının pazarlama sorunu yaşadığını belirtmiştir. Pazarlama sorunun en önemlisini de birlik olmayışına bağlamışlardır. Bu da Türkiye'nin daha doğusuna kalan illerde ceviz yetiştiriciliğinde pazarlama sorunu olduğunun ve bu sorunun birliklerle çözülebileceği sonucu çıkarılabilir. 
Çizelge 6. Üreticilerin ceviz pazarlamasında problem yaşama durumu ve problemleri

\begin{tabular}{|c|c|c|c|}
\hline Açıklama & & Frekans & $\%$ \\
\hline \multirow{2}{*}{$\begin{array}{l}\text { Ceviz pazarlamasında problem } \\
\text { yaşama durumu }\end{array}$} & Problem yaşayan & 3 & 3.00 \\
\hline & Problem yaşamayan & 97 & 97.00 \\
\hline \multirow{3}{*}{ Üreticilerin ceviz pazarlama yolları } & Kendim perakende satarım & 17 & 17.00 \\
\hline & Toptan tüccara satarım & 82 & 82.00 \\
\hline & Diğer & 1 & 1.00 \\
\hline
\end{tabular}

Üreticilerin \%79'luk kısmı ceviz yetiştiriciliğinde problem yaşadığını, küçük bir dilimi olan \%21'lik kısmı ise problem yaşamadığını belirtmiştir (Çizelge 7). Çiftçi ve Gökçe (2006) araştırmalarında ceviz yetiştiricilerinin \%30’unun üretimde sorun yaşamadığını bulmuşlardır.

Çizelge 7. Üreticinin ceviz yetiştiriciliğinde problem yaşama durumu

\begin{tabular}{llll}
\hline Açılama & Frekans & \% \\
\hline Ceviz yetiştiriciliŏinde problem & Problem yaşayan & 79 & 79.00 \\
yaşama durumu & Problem yaşamayan & 21 & 21.00 \\
\hline
\end{tabular}

Çizelge 8'de ceviz yetiştiricilerin yetiştirmede yaşadıkları problemler 5'li likert ölçeğine göre ölçülmeye çalışılmış ve değerlendirme çizelgede verilmiştir. Çizelge 8'e göre yetiştiricilerin en önemli yetiştiricilik probleminin doğal ve iklimsel afetler sorunu olduğu gözlenmiştir. Yetiştiricilerin, ikinci sırada hastalık ve zararlılarla mücadele sorunu, üçüncü sırada ise yetiştiricilik problemleri sorunları yaşadığı belirlenmiştir. Yıldız ve Çolak (2018) Uşak ilindeki ceviz yetiştiricilerinin \%85'inin soğuğun verimi etkilediğini belirtirken, Çiftçi ve Gökçe (2006) İzmir ve Manisa illerinde yaptıkları araştırmalarında ceviz yetiştiricilerinin \%5'inin kuraklıktan etkilendiğini beyan etmişlerdir. Yani yıllar geçtikçe kuraklık ve iklim değişikliğinin yetiştiricilikte sorun olmaya başladığı söylenebilir. Bostan (2012) Bitlis ilindeki ceviz yetiştiriciliğindeki en büyük sorunlardan bir tanesinin zirai mücadele (\%39.07) olarak belirtmesi bu araştırmanın sonucu ile paralel bir sonuç olmaktadır.

Çizelge 8. Ceviz yetiştiriciliğinde problem yaşayanların önem sırasına göre nedenleri

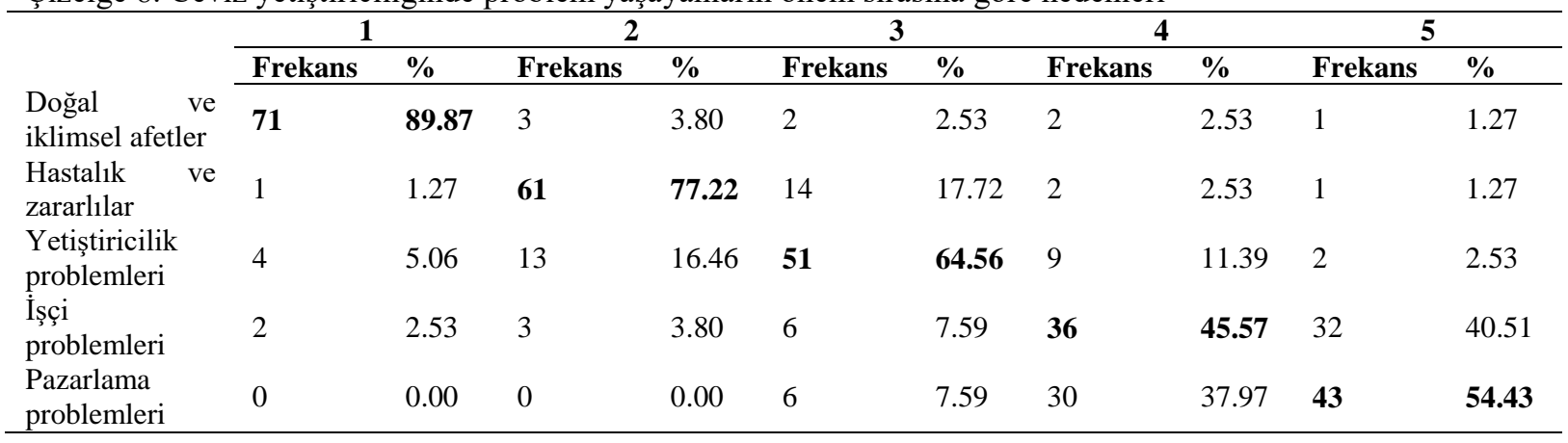

$\mathrm{Bu}$ araştırmada Çorum ili Oğuzlar ilçesinde ceviz üreticilerinin yetiştiricilik problemi yaşamasını etkileyen bazı faktörler binary logit yardımı ile analiz edilmiş ve Çizelge 9'da analiz sonuçları verilmiştir. Analiz sonucunda McFadden $\mathrm{R}^{2}$ ve önem seviyesine göre hipotez anlamlı bulunmuş ve yorumlanabilir çıkmıştır. McFadden $\mathrm{R}^{2}$ analizine göre açıklayıcı değişkenler modelin \%62'sini açıklaya bilmiştir ve bu da kabul edilebilir bir orandır. Modelin önem seviye istatistiki olarak

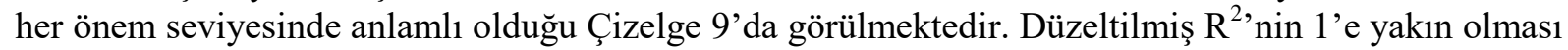
istenilir, modelde 0.89 bulunmuş ve bu da oldukça yüksek bir oran olup modelin yorumlanmasına istatistiki olarak izin vermektedir. Analiz sonucunda ceviz yetiştiricilerin yetiştirme problemi ile yetiştiricilerin yaşı, tecrübesi ve ceviz verimi arasında istatistiki olarak anlamlı bir ilişki bulunmuştur.

$\% 10$ anlam düzeyinde anlamlı bulunan yetiştiricilerin yaşı ile yetiştiricilik problemi yaşaması arasında negatif yönlü bir ilişki beklenmektedir. Yani yetiştiricilerin yaşı arttıkça problem yaşamada $\% 1$ oranında azalması yönünde olması beklenmektedir. \%10 önem düzeyinde anlamlı bulunan yetiştiricilerin ceviz yetiştiriciliği üzerine tecrübesi ile yetiştiricilikte problem yaşama durumu arasında 
negatif yönlü bir ilişki olabilir. Başka bir ifade ile yetiştiricilerin ceviz yetiştiriciliğindeki tecrübesinde bir yıllık tecrübe kazanması yetiştiricilikteki problem yaşama durumunu \%19 oranında azaltması demektir.

\%10 önem seviyesinde anlamlı bulunan ağaç başına ceviz verimi ile yetiştiricilik problemi yaşama arasında pozitif yönlü bir ilişki olması olasıdır. Yani ağaç başına verim artışı problem yaşama sorununu tetikleyebilir. Başka bir ifade ile ağaç başına bir birimlik verim artışı yetiştiricilikte problem yaşama sorununu \%1 oranında artırabilir.

Çizelge 9. Oğuzlar 77 ceviz yetiştiricilerin yetiştiricilik problemi yaşamasını etkileyen faktörlerin binary logit analiz sonucu

\begin{tabular}{llllll}
\hline & Kat Sayı & Standart Hata & $\mathbf{z}$ & $|\mathbf{z}|>\mathbf{Z}$ & Marjinal Etki \\
\hline Sabit & $4.509^{*}$ & 2.694 & 1.67 & 0.094 & $-0.008^{*}$ \\
YAS & $-0.051^{*}$ & 0.031 & -1.65 & 0.099 & 0.007 \\
ED & 0.047 & 0.500 & 0.09 & 0.925 & $-0.183^{* *}$ \\
TECRUBE & $-1.565^{*}$ & 0.851 & -1.84 & 0.066 & -0.003 \\
ALAN & -0.0231 & 0.018 & -1.29 & 0.199 & 0.076 \\
DESTEK & 0.565 & 0.825 & 0.68 & 0.494 & -0.114 \\
UZMANLAS & -0.710 & 0.674 & -1.05 & 0.292 & $0.003^{*}$ \\
VERIM & $0.023^{*}$ & 0.021 & 1.08 & 0.080 & 0.215 \\
TESCIL & 1.172 & 1.144 & 1.02 & 0.306 &
\end{tabular}

Not: $* *, *==>$ Önem seviyesinde temsili $\% 5, \% 10$

Düzeltilmiş $\mathrm{R}^{2}$ : -89.172, Khi kare [8 d.f.]: 234.906, Hosmer-Lemeshow khi-kare: 42.545 , McFadden Pseudo R-kare: 0.621 Önem Seviyesi: 0.000

\section{Sonuç ve Öneriler}

Çorum İli Oğuzlar İlçesinde Ceviz yetiştiriciliği yapan üreticilerin büyük bir çoğunluğu ilkokul mezunu ve Ceviz yetiştiriciliği ile ilgili herhangi bir eğitim almamışlardır. Genelde aile işletmeciliği ile üretim yapılmaktadır. Yetiştiriciler uzun yıllardır ceviz üreticiliği yapmaktadırlar.

Üreticilerin çoğunluğu tescilli Oğuzlar 77 çeşidi ile üretim yapmaktadırlar ve tescilli çeşidin ürüne değer kattığını düşünmektedirler.

Ceviz yetiştiricilerinin pazarlamada pek sorunu yokken yetiştiricilikte birkaç sorun yaşadığ 1 araştırma sonucunda varılmıştır. Yetiştiricilikte yaşanılan sorunlara öneri getire bilmek için istatistiki yönden incelenmek istenmiştir. Bunun için yetiştiriciliği etkileyebilecek bazı sosyo demografik özellikler belirlenip binary logit analizi ile test edilmiştir. Analiz sonucunda ceviz yetiştiriciliğinde problem yaşamayı yetiştiricinin yaşı, yetiştiricilik tecrübesi ve ürünün verimi istatistiki olarak etkilediği sonucuna ulaşıldı. Üreticilerin yaşı ve tecrübesi artıkça ceviz yetiştiriciliğinde problem yaşama oranını azaltmaktadır. Genç yetiştiricilerin veya ceviz yetiştiriciliğine yeni başlayan yetiştiricilerin yetiştiricilikte daha fazla problem yaşaması beklenebilir. Ekim alanı genişledikçe yetiştiricilikte daha fazla problem yaşanması beklenmektedir.

Üretici ya da yetiştiricilerde eğitim seviyesi önemli olduğu birçok çalışmada incelenmiştir. Oğuzlar 77 ceviz yetiştiricilerinin yetiştiricilik problemi yaşama ile yetiştiricilerin eğitim durumları arasında pozitif yönlü bir ilişki olduğu ancak istatistiki olarak anlamlı olmadığı gözlenmiştir. Yani yetiştiricilik problemi yaşama genelde eğitim seviyesi azalması ile doğru orantılı olmalıdır. İstatistiki olarak anlamlı olmayan yetiştiricilerin eğitim seviyesinin yükselmesi yetiştiricilik problemi yaşama olasılığını artırdığı söylenebilir. Buradan sonuç olarak eğitim seviyesi artması daha bilinçli davranmayı dolayısıyla daha detaylı davranışa dolayısıyla yetiştiricilik problemi yaşamasına neden olabilir.

Araştırma sonuçları doğrultusunda küçük aile işletmeleri olan ceviz yetiştiriciliğinde problem olduğu gözlenmiştir. İklim değişikliği gibi doğal afetlerden etkilenen yetiştiricilere sigorta yaptırması ve sigortalatma hakkında eğitim verilmesi önerilebilir. Cevizin değerlendirilmesi için cevizi sadece ham ürün değil katma değer katacak ceviz reçeli, köme/cevizli sucuk gibi ürünlere dönüştürülerek de kadın işletmeleri kurulması önerilebilir.

Not: 03-05 Haziran 2021 Tarihleri arasında yapılan Uluslararası Küresel İklim Değişikliği Kongresi’nde sözlü bildiri olarak sunulmuştur 


\section{Kaynaklar}

Akgül, A., Çevik, O. 2005. İstatistiksel Analiz Teknikleri. Emek Ofset Ltd. Şti. 2. Baskı. s.y. 428. Ankara.

Almeida, C.M., 2020. Walnut production and trade in portugal and in the world context. Revista de Ciências Agrárias. 43(Especial 2): 010-016.

Anonoim, 2021. Oğuzlar İlçesi Kaymakamlığı, İlçe EkonomisiOğuzlar 77 Cevizi, (http://oguzlar.gov.tr/oguzlar77-vevizi), Erişim Tarihi 18 Ekim 2021.

Bayazit, S., Tefek, H., Çalışkan, O. 2016. Türkiye'de ceviz (Juglans regia L.) araştırmaları. Süleyman Demirel Üniversitesi Ziraat Fakültesi Dergisi. 11 (1):169-179.

Ketenci, K.C., Bayramoğlu, Z., 2020. Kırşehir ili Kaman ilçesinde ceviz yetiştiriciliğinin yatırım analizi ve kârlılığın belirlenmesi üzerine bir araştırma. Ordu Üniversitesi Bilim ve Teknoloji Dergisi. 10(1): 1122.

Berenson, M.L., Levine, D.M., 1996. Basic Business statistics concepts and applications. sixth ed.. p. 837. prentice-hall international. New York.

Bostan, T., 2012. Bitlis ilinde ceviz yetiştiriciliğinin ekonomisi, karşılaşılan sorunlar ve çözüm yolları üzerine bir araştırma. Süleyman Demirel Üniversitesi Fen Bilimleri Enstitüsü, Tarım Ekonomisi Anabilim Dalı, Yüksek Lisans Tezi. $91 \mathrm{~S}$.

Çiftçi, K., Gökçe, O., 2006. İzmir ve Manisa illerinde ceviz yetiştiriciliğinin sosyo-ekonomik yönü ve sorunları üzerine bir araştırma. Yüzüncü Y1l Üniv. Ziraat Fakültesi, Tarım Bilimleri Dergisi. 16(1):7- 17.

Gujarati, N.D., 2001. Essential of Econometrics, Mc Graw Hill, New York. Translate: Senesen, U., Senesen, G.G., Literatür Publication No:33, Istanbul.

Güvenç, İ., Kazankaya, A., 2019. Türkiye'de ceviz üretimi, dış cephe ve rekabet gücü. Yüzüncü Y1l Üniversitesi Tarım Bilimleri Dergisi. 29(3): 418-424.

FAO (Food and agriculture Organization). 2020. (http://www.fao.org/faostat/en/\#data/QC), Erişim tarihi 15 Nisan 2021.

Ketenci, C., Bayramoğlu, Z., 2018. Türkiye'de ceviz üretiminin rekabet analizi. Türk Tarım ve Doğa Bilimleri Dergisi. 5(3): 339-347.

Khanali, M., $\quad$ Akram, A., Behzadi, J., Mostashari-Rad, F., Saber, Z., $\quad$ Chau, K.W., 2021. Multi-objective optimization of energy use and environmental emissions for walnut production using imperialist competitive algorithm. Appl Energy. 284: 116342.

Kızılaslan, N., Erdemir, S., 2017. Kaman ceviz çeşidine ismini veren Kırşehir ili Kaman ilçesi'nde ceviz yetiştiriciliği ve ceviz üretim faaliyetleri. Bahçe 46 (Özel Sayı 2: III. Ulusal Ceviz Sempozyumu): 209 225.

Pezikoğlu, F., Öztürk, M., Tosun, İ., Yaşar, A., 2012, Seçilmiş bazı illerde kapama ceviz bahçelerinin üretim ve pazarlama yapısı. Bahçe Dergisi. 41(2): 23-35.

TÜİK (Türkiye İstatistik Kurumu). 2020. (https://biruni.tuik.gov.tr/medas/?kn=92\&locale=tr), Erişim tarihi 15 Nisan 2021.

Ünver, H., Sakar, E., 2011. Türkiye'de ceviz yetiştiriciliğinin durumu ve yapılan seleksiyon çalışmaları. Harran Tarım ve G1da Bilimleri Dergisi. 15(3): 61-59.

Yıldız, E., Çolak, A., 2018. Uşak ili ceviz yetiştiriciliğinin teknik yapısı. Süleyman Demirel Üniversitesi Fen Bilimleri Enstitüsü Dergisi. 22(1): 166-171.

Yiğit, A., Ertürk, Ü., Korukluoğlu, M. 2005. Fonksiyonel bir gıda: ceviz. Bahçe Ceviz 34 (1): 163 - 169. 